\title{
Pathfinders for the Future? Indigenous Rights and Traditional Knowledge in Sweden
}

\author{
Åsa Nilsson Dahlström ${ }^{1}$, Johanna Dahlin ${ }^{2}$ (1) and Håkan Tunón ${ }^{3, *}$ (1) \\ 1 School of Education and Communication, Jönköping University, 55511 Jönköping, Sweden; \\ asa.dahlstrom@ju.se \\ 2 Department of Culture and Society, Linköping University, 60174 Norrköping, Sweden; johanna.dahlin@liu.se \\ 3 Swedish Biodiversity Centre, Department of Urban and Rural Development, Swedish University of \\ Agricultural Sciences, P.O. Box 7012, 75007 Uppsala, Sweden \\ * Correspondence: hakan.tunon@slu.se; Tel.: +46-18-672-591
}

check for updates

Citation: Nilsson Dahlström, ̊̊.; Dahlin, J.; Tunón, H. Pathfinders for the Future? Indigenous Rights and Traditional Knowledge in Sweden. Sustainability 2021, 13, 11195. https://doi.org/10.3390/su132011195

Academic Editors: Asterios Bakolas and James Kennell

Received: 16 August 2021

Accepted: 29 September 2021

Published: 11 October 2021

Publisher's Note: MDPI stays neutral with regard to jurisdictional claims in published maps and institutional affiliations.

Copyright: (c) 2021 by the authors. Licensee MDPI, Basel, Switzerland. This article is an open access article distributed under the terms and conditions of the Creative Commons Attribution (CC BY) license (https:/ / creativecommons.org/licenses/by/ $4.0 /)$.

\begin{abstract}
Indigenous peoples have for the past decades increasingly argued that not only is their traditional knowledge to be recognized in the management of their traditional territories, but that Indigenous control and self-governance over territories and natural resources are crucial for long-term sustainability of the land and cultural revitalisation of its people. In recent years, the Saami in Sweden have also presented themselves as pathfinders, offering advice and solutions for a more sustainable future not only for the Saami society, but for all of Sweden. This paper investigates how Saami claims for rights and stewardship in environmental management are related to Saami cultural revitalisation, within a Swedish colonial framework. It is based on an investigation of the Saami policy positions expressed in policy documents and opinion pieces produced by organisations representing the Saami, linking claims for rights and environmental stewardship with cultural revitalisation and a more sustainable development for all.
\end{abstract}

Keywords: Indigenous peoples; Saami people; traditional knowledge; biological diversity; revitalisation; Indigenous rights; pathfinders; stewardship; cultural heritage; resource extraction

\section{Introduction}

Indigenous peoples have for the past decades increasingly argued that not only is their traditional knowledge to be recognized in the management of their traditional territories, but that Indigenous control and self-governance over territories and natural resources is crucial for long-term sustainability of the land and cultural revitalisation of its people. Indigenous knowledge systems are increasingly used as management resources and in many places, Indigenous peoples are promoted as "stewards", "guardians", or "custodians" of land, resources, and heritage. In recent years, they have also been held forward as "pathfinders" and their ways of life as models for sustainable development more generally. Such perspectives are also present in the international work processes within the UN Convention on biological diversity (CBD) and the Intergovernmental SciencePolicy Platform on Biodiversity and Ecosystem Services (IPBES). However, Indigenous-led conservation drives are not only about environmental management, but also have social, cultural, and political significance. Therefore, it is implied that sustainability is linked to cultural revitalisation and a recognition of Indigenous rights.

The strategy of promoting Indigenous stewardship criticizes the assumed separation of knowledge from people, which has often resulted in reducing Indigenous peoples to mere informants and stakeholders in the management of their traditional territories. The notion of stewardship also suggests a specific responsibility, of humanity generally and/or Indigenous peoples specifically, towards nature. Implicit in the strategy is the idea that Indigenous peoples are uniquely capable as stewards, by virtue of being Indigenous peoples and (therefore) carriers of Indigenous traditional knowledge. The strategy also 
taps into the idea that Indigenous traditional knowledge and customary ways of life are inherently sustainable and can therefore contribute to a sustainable development of their traditional lands and societies, as well as providing inspiration for sustainable development more generally.

The development is linked to the emergence of a global legal framework for indigenous rights. The "globalisation of law", i.e., the degree to which the whole world lives under a single set of legal rules, including new international conventions and declarations, transnational organisations, and judgments by international courts, has provided a framework for the increasing recognition of Indigenous peoples' rights in the last decades. Three of the most important instruments are the 1989 ILO Convention Concerning Indigenous and Tribal Peoples in Independent Countries (No. 169) and the UN Convention on Biological Diversity (CBD) from 1992, and more recently the UN Declaration on the Rights of Indigenous Peoples (UNDRIP) adopted in 2007. Indigenous stewardship of traditional territories does not, however, necessarily solve the problem of colonial entanglement, i.e., when the environmental management regimes require Indigenous participants to resist and contribute at the same time to the distribution of bureaucracy by (reluctantly) participating on its terms. This is often reflected in the compliance with conventional environmental discourses that Indigenous Peoples must display in interactions with state representatives, to be able to voice their claims.

In this paper we will turn to Sweden, where the Indigenous Saami over the past decades, in response to these global political processes and inspired by, for instance, the UN Conference on Environment and Development (UNCED) in 1992 and CBD, have increasingly positioned themselves as carriers of traditional ecological knowledge that can be useful in creating a sustainable development, and as rightsholders by virtue of their status as an Indigenous people. Although Sweden has not ratified the ILO169 and has made selective endorsements in the implementation of UNDRIP, these legal instruments have had a profound impact on the way the Saami have positioned themselves and developed their arguments for more control over Saami-related issues in Sweden.

The global discourses on Indigenous peoples have also fuelled a cultural revitalisation process for the Saami, who are connecting their traditional knowledge to the survival of Saami languages and culture, and to claims for a recognition of Saami worldviews and ethics in environmental management.

\section{Aim}

This paper investigates the Saami claims for stewardship in environmental management and how these claims can be understood within Saami cultural revitalisation processes and a Swedish colonial framework. We do not attempt to determine the practical validity of the claims. The paper focuses on how the Saami are positioning themselves in policy documents, and how Saami environmental stewardship is claimed to benefit both the Saami society and the sustainable development of Sweden generally. The research questions that will be asked in this paper are:

- How can the Saami claims be related to positions as stakeholders, rightsholders, environmental stewards, and pathfinders?

- How are claims of the benefits and specificity of Saami traditional (ecological) knowledge expressed in policy documents and opinion pieces by Saami organisations?

\section{Materials and Methods}

This paper is based on an analysis of policy documents and opinion pieces produced by Saami organisations in Sweden, and of relevant international conventions and reports that Saami organisations refer to. A review of existing scholarly literature within the research fields of traditional knowledge, the "globalisation of law", and Indigenous peoples' rights provide the framework for analysis.

The traditional Saami territories called Sápmi stretch over four countries: Norway, Sweden, Finland, and Russia. The Swedish part of Sápmi is best described as the geograph- 
ical areas that are included in the different year-round and winter grazing financial and administrative districts for the 51 legally recognized reindeer herding communities, to which all Saami reindeer herders in Sweden belong as members, and where all reindeer herding in Sweden takes place. Together, these cover about $50 \%$ of Sweden's total area, which corresponds roughly to the northern half of the country. The number of Saami in Sweden is estimated at $20,000-40,000$ individuals $(0.2-0.4 \%$ of the total population), but since Sweden does not register its population according to ethnicity, the number of Saami in Sweden may be higher.

In 1977, the Saami were recognized by the Swedish Parliament as an Indigenous people, and since 2011 in Swedish constitutional law as a People. In 1993 the Sámediggi (the Swedish Saami parliament) was established, which is both a government authority responsible for Saami culture and livelihoods and a publicly elected parliament for the Saami people. The Saami people is also since 2000 recognized as one of five national ethnic minorities in Sweden, together with Swedish Finns, Tornedalers, Roma, and Jews, and are protected by law since 2010. The majority of Saami live in Sápmi, but there are Saami living in all parts of Sweden [1] (p. 5). Around 2500-3000 Saami in Sweden have reindeer herding (meat production) as their main source of income, but many more Saami own reindeer that are taken care of by professional herders. Other traditional Saami livelihoods include hunting, fishing, and duodji (sloid and craft), which are often combined with small-scale agriculture or Saami tourism, but Saami people in Sweden work in many different job sectors [2].

The documents selected for analysis in this paper are all public statements and policy documents from the Sámediggi (the Swedish Saami Parliament) and Sámiid Riikkasearvi (the Swedish Saami Association), in addition to the report Mijá Ednam from the Saami reindeer herding communities in the World Heritage site of Laponia, and to international conventions and reports of relevance to the study, all published between 1992 and 2021. We have chosen 1992 as our starting point since this is when the CBD was adopted, which fuelled the current Saami revitalisation processes. All documents are publicly accessible as on-line resources via the websites of the publishers or organisations. The publications were selected according to their relevance for expressing Saami claims for rights, participation in environmental management, and environmental stewardship, and for representing an official Saami policy position in Sweden. The policy documents were analysed using discourse as well as frame analysis, investigating not only what concepts are used and how the policy texts are formulated in relation to other activities and texts, but also what frameworks that the authors of the policy texts were engaged in and responding to when formulating those policies. By placing the texts in the policy documents in relevant contexts, it is possible to trace the parallel development and sometimes mutual exchange of ideas among several stakeholders over time.

\section{Results and Discussion}

\subsection{Indigenous Rights and Saami Claims in Sweden}

The status of the Saami in Sweden is ambiguous, and although the Swedish Parliament recognised the Saami as an Indigenous people of Sweden in 1977, it did not result in any real changes of the situation for the Saami. The recognition of the Saami as a People with a right to self-determination in 2006 (in the Swedish constitutional law since 2011) also did not specify the content of this right or its potential effect on the mandate of the Sámediggi, whose administrative duties remain limited to Saami cultural issues, including the Saami languages and administration of reindeer herding [3].

Sweden has a self-image of being a "good state" [4] that adheres to the welfare and rights of its own citizens, as well as citizens of other states [5]. This is expressed in support for the United Nations, human and minority rights, gender equality, and international aid [6]. However, when it comes to Saami rights there has been a "gap between talk, decisions and action" [7] (p. 9) and Sweden has been criticized on an international level for its inability to recognise Saami land rights [3] (p. 1728). 
Sweden only rarely refers to its own colonisation of Sápmi [8] (p. 1); [9] or to its role in European colonialism worldwide [10] (p. 18). Its national narrative is based on the perspective from the majority population [9] and has excluded less flattering historical aspects that are inconsistent with its self-image as a benign state that cares for people $[4,6]$. It is therefore difficult to find explicit statements relating to "colonialism" to describe the relationship between the state and the Saami, and few representatives for the Swedish state would see themselves as proponents of colonialism [11] (p. 34). Many scholars have used the term "colonial" in relation to Sápmi (e.g., [12-14], but the description of the Swedish expansion into Sápmi as colonialism remains controversial [15] (p. 26). Moreover, a Saami Commission appointed by the Swedish government in 1982 found that the international legislation for Indigenous peoples did not apply for Sweden, since the Saami were colonised by "internal colonisation" and not colonisation by overseas states [16] (p. 101).

In Sweden, the political discourse has therefore not included an explicitly colonial perspective on the north but has simply focused on whether this part of the country ought to be exploited for agricultural and/or industrial purposes [17]. Thus, Sweden has officially or explicitly not colonised Sápmi [18], and yet during the past two centuries, the Swedish exploitation of the resources of the north has increased, and a parallel process of systematic degrading of Saami identities, culture, and livelihoods have occurred through state actions [11] (p. 34). The hydropower and the timber from rivers and forests in the north are often referred to as primary industries for Sweden as a (welfare) state [19], and the mining industry is to a large extent concentrated to locations in Sápmi, both when it comes to active mines and planned explorations [20,21] (p. 157). According to the Mining Inspectorate, nine of the twelve mines that were in operation in Sweden at the time of writing are within the reindeer herding area. These represent more than $75 \%$ of the total ore value as the biggest mines are all located in Sápmi.

Until the mid-18th century, however, the position of the Saami was relatively strong because of their contribution to tax revenues from their trade with produce from reindeer, fish, game, and fur, and because of their specialist knowledge in hunting and handicraft, and skills in trades that Swedes were reluctant to carry out, such as the slaughtering of horses. The presence of taxpayers was also important to the Swedish state for staking claims to the territory in times when national borders were not yet fixed. Therefore, the Saami enjoyed several privileges to ensure that they stayed, used their lands, and continued to pay their taxes [22]. They had their own representation in the Swedish parliament 1602$1765 / 66$ and therefore potentially had direct influence over their livelihoods, although it is unclear to what extent this right/obligation to send a representative to the parliament was exercised [22] (p. 76). At the end of the 17th century, the Swedish government started campaigning for settlers to go to Sápmi, but it was not until the end of the 18th century that the number of settlers from southern Sweden started to increase, and the people settled on traditional Saami lands, without compensation to the Saami $[23,24]$. The industrialisation from the 19th century onwards further marginalised the Saami and their traditional livelihoods in favour of mining, hydropower, and forestry. At the same time, the emergence of nationalism and new racist policies in Sweden labelled the Saami as an inferior race [18,22].

In the 20th and 21st centuries, the Saami in Sweden have on several occasions tried their rights in court, and although few verdicts have been in their favour, for each verdict the courts have clarified some aspect of the status of the Saami and their rights, i.e., in the cases of Skattefjällen 1981, Härjedalen 2000, Nordmaling 2011, Rätan 2012, and Girjas 2020. During the Skattefjällen court process in 1977, Sweden recognised the Saami as an Indigenous People and as a minority in Sweden, and although the Saami Commission found that the international legislation did not apply for Sweden, the Saami were considered to fulfil the criteria for an ethnic and linguistic minority group according to the International Covenant on Civil and Political Rights (ICCPR, article 27) and as such entitled to protection of its own culture, religion, and language. In Sweden this was seen as a "right to cultural autonomy", including reindeer herding, as a precondition of Saami culture [16] (p. 101). 
Although the social and cultural rights of the Saami have been acknowledged, Sweden is persistently reluctant to ratify the Indigenous and Tribal Peoples Convention from 1989 (ILO169), that includes a formulation in Article 14.1 that Swedish governments have had difficulties accepting:

"The rights of ownership and possession of the peoples concerned over the lands which they traditionally occupy shall be recognised. In addition, measures shall be taken in appropriate cases to safeguard the right of the peoples concerned to use lands not exclusively occupied by them, but to which they have traditionally had access for their subsistence and traditional activities. Particular attention shall be paid to the situation of nomadic peoples and shifting cultivators in this respect."

The Swedish position has been explained in different terms, such as incompatibility with the Swedish legal tradition, legal difficulties with recognising the types of ownerships and users' rights associated with reindeer herding, wide-ranging legal and financial consequences of ratification, and fears that ratification might lead to conflicts between the Saami and the non-Saami population. Several comprehensive investigations on Saami land, fishing, and hunting rights have been launched [3] (p. 1726, 1727), and the slowness of the processes have often been justified as taking responsibility for a difficult question [11]. However, subsequent governments have declared that a ratification of the ILO 169 is a major objective, but not possible here and now [3].

The recent Girjas court case (2020, Girjas reindeer herding community vs. the Swedish state) has provided a partly new legal interpretation of Saami rights in Sweden. The Supreme Court acknowledged the Indigenous Saami claims for concession rights over small game hunting and fishing in the reindeer herding community of Girjas, based on their immemorial rights to these practices in that area, while dismissing the concession rights of the state. However, immemorial rights can be claimed by any long-time users of a natural resource and not only Saami people, which means that the verdict is based on their historical practices rather than on their status as an Indigenous People. In the Girjas case, the Saami of the Girjas reindeer herding community based their rights claims on their status as an Indigenous People under international law, but the state rejected all such references and argued that the fact that the Saami are an Indigenous people was irrelevant to the case. Instead, the rights granted by the Swedish Supreme Court to Girjas were based on their immemorial rights to herd reindeer in that specific area. However, despite Sweden's non-ratification of the ILO 169, the Supreme Court did state in the Girjas verdict that some instruments that regulate Indigenous rights are binding for Sweden, despite non-ratification, since these form part of established international norms. In addition, these instruments have been important in Sweden since they provide a normative framework for Saami claims for rights [3] (p. 1736); [25] (p. 431).

The Girjas reindeer herding community had the court verdict in their favour, but as with other court cases, it is limited to issues in specific territories and about specific resources and does not automatically apply to the entire Sápmi, but because a verdict from the Swedish Supreme Court is prejudicial it will have an impact on future cases. Although costly and time-consuming, the increasing use of litigation as a political strategy for the Saami is the result of the lack of clarification of Saami rights in Swedish legislation, and a frustration over having to ask for favours instead of exercising what the Saami perceive to be their rights as an Indigenous People.

Another legal difficulty in Sweden is that many Saami rights issues are related to reindeer herding and are based on the strictly regulated membership in a reindeer herding community, which is exclusive to the Saami, but only a minority of the Saami population is eligible for membership. Most court cases have involved the rights of herding communities, but there is also a need for investigating the rights for the Saami who are not members of such communities. Historically, many Saami were forced by Swedish authorities to give up their reindeer herding, in response to the hardening of the Swedish-Norwegian border and so-called social welfare programs. Other reindeer herders were forced to leave their home 
areas and migrate long distances to southern Sápmi with their reindeer, and many families were separated as a result. These forced migrations in the early 20th century have had a very negative impact on Saami society [26]. The focus in Swedish courts on continuous and immemorial rights to certain areas and livelihoods and the emphasis on reindeer herding community membership to access Indigenous rights is therefore considered unfair by many Saami families who never practiced reindeer herding, had to give up reindeer herding, or who suffered from the forced migration from traditional areas, but who still identify as Saami.

Although the Saami struggles for rights began several hundred years ago, when the Swedish state first started to encroach on Saami traditional lands, the development of global Indigenous rights has provided new arguments for the Saami. The UN Conference of Environmental and Development in Rio de Janeiro in 1992 resulted in numerous documents relevant for the situation of Indigenous peoples. In the 22nd principle of the Rio declaration on Environment and Development it is stated that:

"Indigenous peoples and their communities and other local communities have a vital role in environmental management and development because of their knowledge and traditional practices. States should recognize and duly support their identity, culture and interests and enable their effective participation in the achievement of sustainable development."

The current Saami revitalisation process is related to the developing global framework of Indigenous rights; not least the development of the CBD and its article 8(j), which outlined the importance of (Indigenous) traditional knowledge for sustainable development, by stating that each contracting party shall:

"respect, preserve and maintain knowledge, innovations and practices of indigenous and local communities embodying traditional lifestyles relevant for the conservation and sustainable use of biological diversity and promote their wider application with the approval and involvement of the holders of such knowledge, innovations and practices and encourage the equitable sharing of the benefits arising from the utilization of such knowledge innovations and practices."

The CBD (article 10(c)) has also had an important impact on the development of Saami policy for the protection and the sustainable development of resources in Sápmi, stating that each party shall "(p)rotect and encourage customary use of biological resources in accordance with traditional cultural practices that are compatible with conservation or sustainable use requirements".

In 1996, the Sámiid Riikkasearvi (the Swedish Saami Association) developed a Saami action plan for environmental adaption of Saami businesses, inspired by Agenda 21, and even though the environmental considerations are well presented, the role of Saami people as particularly ecologically enlightened is not a central argument [27]. However, since at least 1998, there has been a Saami representation in the Swedish national delegation to CBD negotiations, and, consequently, the Saami society has had plenty of opportunities to influence and be influenced by other Indigenous Peoples and the international discussions.

Another important event for the Saami was the appointment of Laponia as a World Heritage site in 1996, which created a lot of attention, not least in the local Saami reindeer herding communities within Laponia, who mobilised to position themselves as stakeholders in its management. These events, which were the result of global processes and an increasing interest in traditional knowledge and Indigenous heritage and rights, inspired and transformed the Saami claims for rights in the Swedish context. Throughout the revitalisation process, the Saami have also argued that their traditional knowledge and sustainable way of life is intimately connected to the survival of the Saami languages and culture, including reindeer herding. In recent years, the Saami have also expressed their views on strategies for sustainable development, often in relation to climate change and loss of biodiversity and base their claims on their status as an Indigenous people with valuable knowledge for creating sustainable development more generally. 
The arguments in most policy documents and reports written by Saami representatives are based on their management capacities and their unique traditional ecological knowledge, in line with the arguments presented in global policy documents and reports such as IPBES [28] (p. 14, 18, 44), which, if implemented, promises a more sustainable development than the conventional environmental knowledge that forms the basis for Swedish policy. In most policy documents and reports, the Saami are asking to be at least consulted, preferably acknowledged as stakeholders or maybe even co-managers, but the Saami rarely articulate an actual demand for self-determination.

Discussion: Saami rights in Sweden in 2021 are based on their status as an ethnic and linguistic minority, and as a People and an Indigenous people. As an Indigenous People, the arguments from the Saami for greater influence over traditional areas and resources are guided by the development of international law on indigenous rights and supported by international conventions and policies such as ILO169, CBD and IPBES. However, successive Swedish governments, and up until recently also the courts, have dismissed Saami claims based on Indigeneity and instead referred to the Saami immemorial rights to customary practices, or to their cultural rights as an ethnic and linguistic minority. These are rights that are not exclusive to the Saami, that fail to recognize the unique position of reindeer herders in land use decisions, and that treat them as just another land user and as one minority group among several others. The dismissal of Saami claims based on indigenous rights in Swedish courts has forced the Saami to use litigation as a political strategy, but the verdict in the Girjas case (2020) points in a new direction, towards a recognition in Sweden of the Saami as rightsholders according to international legal praxis - a position that opens up for greater influence over not only their culture and heritage, but also their traditional areas and natural resources, even without a formal ratification of international conventions on Indigenous rights by the Swedish government. The Swedish policy also divides the Saami into reindeer herding and non-reindeer herding groups with different rights. This is another example of how the Saami political and cultural revitalisation process has departed from global frameworks for Indigenous rights based on identity, which Saami organisations prefer to refer to, and then landed in a regional and national setting, where Saami rights are negotiated by Swedish authorities on a case-by-case basis, and with references to Saami livelihoods and historical use of lands and resources.

\subsection{Consultations, Co-Management, Self-Governance, and/or Self-Determination}

Indigenous rights are important preconditions for greater involvement in environmental management and usually also entail the duty to consult and to develop co-management regimes or self-governance structures with Indigenous peoples. Co-management of Indigenous natural and cultural heritage has been promoted as the solution to problems with vulnerable communities and conservation of valuable resources, while improving the relations between the state and Indigenous peoples [29,30]. It has also been presented as a useful bridge between the state and Indigenous self-determination [31,32] and between the state as owner and local communities as users of resources; sometimes with the market as an additional stakeholder [33].

Co-management has become common in fields like conservation, fisheries, tourism, and local development projects $[32,34,35]$ but has also become criticised for being a "softer way for governments to access Indigenous lands" [36] (p. 310). Notably, there are many similarities between today's co-management agreements and treatymaking during the colonial period, where Indigenous peoples are offered co-management in areas where the state has jurisdiction. This means that the state can remain in control while having the ability to alter the agreement if there is an overriding interest for another kind of use of the lands and resources [37].

Co-management approaches have come in many different forms, such as joint, cooperative, collaborative, participatory, and multiparty management [12] (p. 37) and have been efficient in channelling Indigenous activism into less threatening management structures 
than those preferred by Indigenous peoples, including land rights and self-determination. Co-management controls the inclusion of indigeneity, and "assimilates" Indigenous perspectives that may otherwise have been used to criticise it, which has resulted in that co-management is often not about managing cultural heritage, but about managing Indigenous sovereignty [12] (p. 35).

Arnstein's well-known "ladder of citizen participation" [38] has inspired research about participation and provides a guide for measuring who has power when decisions are being made. From the bottom rung up, the ladder consists of eight stages of participation: manipulation and therapy (non-participation), informing, consultation, and placation (tokenism), and partnership, delegation, and citizen control (citizen control). The Saami in Sweden have at best reached the level of tokenism when it comes to participation in decisions of interest to them, typically in the form of being informed by state authorities and other stakeholders of plans, of being consulted via surveys or public meetings, and sometimes via representation in committees; however, without real power, which remains with power holders, i.e., state authorities. The only example of partnership and delegation is the Laponiatjuottjudus joint management committee for the Laponia World Heritage site (discussed in more detail below); however, its mandate to act is delegated from central and regional conservation authorities. While Laponiatjuottjudus can be seen as successful co-management, it is far from Indigenous governance [12] (p. 33) and may perhaps be "seen as a local success more than an Indigenous one" [39] (p. 208).

The international rights law that has been developed over the last decades has also partly been based on the principles of the duty to consult, i.e., that the state must consult with Indigenous communities before planning resource developments on their lands. Procedural or participatory rights have been expressed in, for instance, the United Nations Declaration on the Rights of Indigenous Peoples (UNDRIP), ILO 169, and the Committee on the Elimination of Racial Discrimination (CERD) [7] (p. 5). There are also international human rights standards for extractive developments on Indigenous peoples' traditional lands, including the right to free, prior, and informed consent, which require consultations [3] (p. 1727). The standards mean that states must provide a legitimate aim for the exploitation, i.e., a substantial public need, and make sure that Indigenous peoples are not unfairly disadvantaged. Industrial projects that result in "destroying or risking the sustainability of the Indigenous peoples' way of life are therefore clearly violating Indigenous peoples' human rights" [40] (p. 161).

A common interpretation of what degree of influence Indigenous Peoples should have on decision making is that the state must genuinely seek, but not necessarily reach agreements with, Indigenous communities prior to resource developments [7] (p. 5). The Saami in Sweden have insisted on the right to at least be consulted on matters of importance to them, but frequently have also argued for formal representations on boards and committees dealing with issues of interest to the Saami. However, contemporary legislation on extractive industries does not specify an explicit duty for the state to consult with the Saami as an Indigenous people. The tendency by the state to delegate the duty to consult with the Saami to developers has also failed due to a reluctance or inability of developers to formalise policies for direct consultation with the Saami [7] (p. 6). As a result, consultations are often merely an information exchange with little room for real Saami influence [41] (p. 68).

The Swedish state has therefore not yet been able to establish a model for how and when the Saami must be consulted, and a recent government bill was withdrawn (2021) after severe criticism both from Saami organisations and the corporate sector. Following the Girjas verdict in 2020 a government inquiry into the Reindeer Herding Act, including hunting- and fishing rights and by implication land rights generally, have been launched, and this is welcomed by the Samédiggi since it is necessary

"to create modern Saami politics and adapt the legislation in Saami rights issues to immemorial rights, customary use, existing legal praxis, and to (the fact that) 
the Saami people is both a People and an Indigenous people with the rights that follow from this" [42].

Although Saami organisations are insisting on being consulted over matters of importance to the Saami, and to formalize their participation in environmental management, the only formal co-management regime that has been developed between Swedish authorities and Saami representatives was the result of the appointment of a vast area in northern Sápmi as a World Heritage site. In 1996, Laponia was appointed a World Heritage site by UNESCO for its natural and cultural values, based on Outstanding Universal Values of the natural landscape and the Saami cultural heritage and reindeer herding in the area. This was the end of a long process, that had started as an attempt from the Swedish government to nominate Laponia as a "vildmark" (wilderness area), but after criticism from the Sámediggi, the Swedish National Heritage Board, and UNESCO advisors, the Saami cultural heritage and reindeer herding was added very late in the nomination process as cultural values in an "additional document", and Laponia was instead successfully nominated in the natural/cultural "mixed site" category. At the time of the appointment there were no plans to involve the local Saami in the management of the site, and no Saami representatives were invited by the Swedish delegation to the UNESCO appointment ceremony in Merida, Mexico in 1996 [43].

Laponia overlaps nine reindeer herding communities in the municipalities of Jåhkåmåhkke/Jokkmokk and Jiellevárri/Gällivare. The appointment, and the previous reluctance from Swedish authorities to regard Laponia not as a wilderness but as a Saami cultural landscape, triggered a response from the reindeer herding communities, who jointly claimed a position in management and decision-making bodies for the new World Heritage site, based on their extensive knowledge and past and present use of the area. The reindeer herding communities in Laponia expressed their claims in a report called Mijá Ednam ("Our Land") (1999), which was inspired by the global recognition of Indigenous traditional knowledge and rights, expressed primarily in the CBD (1992, articles 8(j) and 10(c)). In the report, the reindeer herding communities expressed their wish to have the opportunity to develop their culture, business ventures and lives, "in Laponia as well as in the rest of Sápmi" and to have "complete influence in issues that relate to our culture" [44] (p. 8). In the final words of the report, it was argued that the suggestions from the reindeer herding communities to create a tailor-made management form for Laponia, "that permits a strong local and Saami representation" in the decision-making body "can seem drastic and foreign in a Swedish perspective", however the report pointed out that this suggestion was not in any way revolutionary, but reflected an ongoing international trend [44] (p. 76).

In the report, the local Saami based their claims on their status as an Indigenous people but focused more on their capacity as good managers of their lands and resources. Traditionally, it was argued, the Saami "have seen nature, culture and our living as an inseparable unit" and have "lived off, and in, nature and have been careful to live off "the surplus" of what nature has provided" [44] (p. 8). For thousands of years, it was argued, the Saami have used their knowledge, traditions, and motivation to manage their traditional lands "without leaving major traces in the landscape-in spite of new times and technology" [44] (p. 9).

With their knowledge and determination to take responsibility for the preservation of the natural and cultural heritage in Laponia, the local Saami argued that they "are particularly suitable for preserving the Saami culture in the area" [44] (p. 9) and that "they are the most suitable to develop effective goals at least in their own industries" [44] (p. 37), but that they "welcome an equal cooperation with other stakeholders" in a management model "where the majority in decision-making bodies is Saami" [44] (p. 9). The Saami also wanted a formal role, such as a coordinating or controlling function, for example for tourist ventures [44] (p. 39) and argued that "crucial considerations and decisions must be made by the members of the reindeer herding communities" [44] (p. 71).

Apart from suggesting a joint management regime for Laponia, the reindeer herding communities also suggested that they should have the responsibility for the maintenance 
of cabins and walkways in Laponia [44]. These suggestions later partly became reality when the Laponiatjuottjudus (derived from the Lule Saami word "tjuottjodit", meaning "to manage") joint management body was established to manage the World Heritage site, and when the economic cooperation Badjelánnda Laponia Tourism was created, and three local herding communities took over the responsibility for the management and maintenance of the cabins and tracks along the Badjelánnda track in Laponia. Since 2011 Laponiatjuottjudus, which includes the nine herding communities, representatives from the county administration, the Swedish Environmental Protection Agency, and the two local municipalities, manages Laponia in accordance with the management plans, which must be approved by authorities at national and regional level. Despite the Saami majority in the Laponiatjuottjudus management body, then, they do not have the ability to exercise their own authority over the World Heritage site. However, decisions are made by consensus which provides some opportunities for the Saami representatives (as well as for the other parties) to withhold their consent to unwanted developments [45].

In other parts of Sápmi, and in the absence of formal consultation or co-management arrangements, Saami organisations are increasingly involved in protests against resource extraction that threaten the integrity of traditional Saami territories, resources and cultural values. The Swedish part of Sápmi is rich in natural resources of national importance, but the use and extraction of those resources is frequently contested. The fact that the Swedish state and private companies are extracting great wealth from Sápmi is sometimes used to lend support to Saami arguments of colonialism. The Sámediggi has issued several policy documents and statements regarding resource use in Sápmi. In the past decade, the most high-profile conflicts have developed around mining, but wind power development is also a hot topic and forestry is probably the extractive industry that has had the greatest impact over time. Hydropower development has also been controversial and has had great and continuing impact, but as rivers are already regulated this issue can be considered "closed" for the moment.

In the Saami policy documents about resources and land use, a specific Saami worldview is presented that informs the documents and Saami land use in general, but also provides a source of learning for others. The Saami way of life is promoted as a model for sustainable development in all of Sweden. According to the Sámediggi's wind power policy, copied in the mining policy, the

"Saami perspective of how natural resources should be used is a role model for others who want to find a new approach to the use of land and waters. In many respects, the majority society can learn from the Saami perspective. In times like these when we must all find new ways of living to prevent climate change, the Saami way of relating to nature can be a model for others" [46] (p. 9), cf. [47].

The policy document on mining and mineral extraction was adopted by the Sámediggi in 2014 (Sametingets syn på mineraler och gruvor i Sápmi, henceforth the mining policy). It was preceded by a statement in 2013, which was read at the site of protests against explorative work for an iron ore mine in Gállok/Kallak outside Jåhkåmåhkke/Jokkmokk. It also referred to the controversial mining project in Raavrhjohke/Rönnbäcken, Lusspie/Storuman and along the lines of global rights discourses labelled both these ongoing projects as "flagrant violations of human rights", especially the rights of the Saami as a People and an Indigenous people to self-determination. The 2014 mining policy document was followed by a demand on a moratorium on extractive projects in Sápmi, until Sweden has ratified ILO 169 and the Nordic Saami convention (a draft version is currently under negotiation, and has not yet been ratified by Norwegian, Swedish, and Finnish parties). The policy document also demands a revision of the Swedish Minerals Act (SFS 1991:45), which is described as an exploitation law that does not respect the needs of reindeer herding or other Saami activities, nor their rights to land and water. The suggested revision includes a veto right for the Sámediggi, for 'affected Saami', and for reindeer herding communities, and a raised fee for the extraction of minerals in the form of royalties, which would benefit a new fund for Saami industries and Saami social development. 
The Sámediggi mining policy is based on a clearly formulated rightsholder perspective and has provided the basis for the Saami arguments against further extraction, for instance in the Gállok/Kallak case. However, in the Gállok/Kallak case, this rightsholder perspective has not been acknowledged by the Swedish authorities, even when they agree with the Sámediggi on the factual issue [48]. This 'rightsholder position' is based on international law, and in several conflicts around mining in Sweden, Saami representatives have appealed to international organs such as the UNESCO in the case of Gállok/Kallak and CERD in the case of Raavrhjohke/Rönnbäcken.

In the Raavrhjohke/Rönnbäcken case, the granting of a mining lease for a nickel mine was submitted to CERD for assessment by local Saami groups, after the case was unsuccessfully processed to government level in Sweden. In 2020 CERD announced its recommendation to stop the establishment of the Raavrhjohke/Rönnbäcken mining project and called on Sweden to revise its mining legislation to acknowledge the rights of the Indigenous Saami people to be consulted and give their free, prior, and informed consent to large scale industrial establishments on Saami territory. The CERD recommendation is that large-scale industrial establishments in Sápmi should be "prohibited without the consent of Saami rightsholders" and that the Swedish state must take an active role in ensuring that the rights of the Saami are respected, instead of referring the negotiations to the Saami communities and the stakeholders from the industry to find "consensus solutions" on their own [3]. The CERD recommendations to the Swedish government have not yet been implemented, but the Raavrhjohke/Rönnbäcken mine development is currently on hold, and while this is the result of a business decision, it may have been influenced by the local opposition to the project. However, there are some signs recently of a potential reactivation of the extraction plans for the mine.

The mining policy begins by establishing the Saami as an Indigenous people, which has lived and taken care of land and water (in Swedish the word "förvaltat" is used, i.e., managed as a steward) in Sápmi with great respect and care since times immemorial. The policy expresses a deep connection between the people and nature, described as a "direct relation", i.e., that Saami people and culture are dependent on nature in Sápmi. The traditional way of life is portrayed as sustainable, based on long-term perspectives and a sustainable use of renewable resources. The rhetorical figure of "bruka men inte förbruka", i.e., using without exhausting resources, is used in not only the mining policy but also in the wind power and climate strategy policy, in opposition to 'extraction', which, by definition, is unsustainable [49] (p. 62). The mining policy also refers to biodiversity, stating that the $\mathrm{CBD}$, article 10 (c), stipulates a protection for sustainable traditional customary use of biological resources, which means that according to the Saami policy, Sweden is required to promote and protect Saami traditional livelihood and Saami culture also in the case of mining [47] (p. 7).

Following the rightsholder perspective and the specific relation between the Saami and nature, the mining policy also stakes a claim on resources in Sápmi: " ... land and water resources in Sápmi are first and foremost for the needs of our industries (näringar) and for the survival of our culture" [47] (p. 5). The mining policy also states that, with a reference to UNDRIP, article 26, that: "all natural resources above and underground within the Saami traditional area, belong to the Saami people" (p. 6). The policy invokes the right to self-determination, as established by the UN convention on civil and political rights (articles 1 and 27) and UNDRIP (articles 3 and 4). It also frames mining as a cultural issue, with reference to UNDRIP and the Swedish law on minority languages, which should promote the preservation and development of Saami culture, not least with respect to children, suggesting that the law on minority languages should be implemented in the processes around mineral extraction.

Questions of mineral extraction and industrial development are naturally often related to land use issues. In 2010, the Sámiid Riikkasearvi produced a report on Saami land use and involvement in Environmental Impact Assessments, which also called for Social Impact Assessments to better address impacts of industrial developments, arguing that the current 
legislation already provides for an assessment of cultural and social impact [50] (p. 6) even if this is rarely recognised in practice. UN bodies have also provided longstanding criticism of the Swedish government for the lack of regard of Saami rights in impact assessments and permitting processes [7] (p. 6). Standard practice in Sweden is that of entirely corporateowned impact assessments, and the developer generally has a responsibility to meet and hear the views of the directly-affected Saami communities but retains full authority to decide how to interpret and use community inputs [7] (p. 5). However, developers generally lack methods to account for cumulative effects and for including Saami traditional knowledge in impact assessments [41]. Sectoral legislation, most notably the Minerals Act (SFS 1991:45), may also limit the possibilities for those affected to influence the process. Although legislation and official policy documents dwell on the principles of free, prior, and informed consent, it is made clear that "consultation" is not the same as "consent". In a clarifying message to the UN regarding the adoption of UNDRIP, the Swedish government pointed out that free, prior, and informed consent should be "interpreted as a guarantee that Indigenous peoples must be consulted, not as giving them a right to veto" [51].

In line with the Sámediggi policies, the environmental impact assessment report from the Sámiid Riikkasearvi in 2010 presents a picture of the Saami as part of the entirety that constitutes their living environment, which consists of the surrounding landscape, the history, reindeer, language, natural resources, and their own place in all this, which form the basis and the preconditions for the entire Saami culture and existence. This is a holistic worldview that the Saami are said to share "with other Indigenous peoples all over the world", but that differs from conventional Swedish perspectives of nature and conservation [50] (p. 5). According to Sámiid Riikkasearvi, many business ventures in Sápmi have not realised the need for a deeper engagement and understanding of Saami rights and environmental perspectives and the responsibility that this entails. However, impact assessments that include the perspectives of the Saami "will contribute to a sustainable development in Sápmi as well as in all of Sweden", it is argued, in addition to developing good working relations with Saami stakeholders and local societies [50] (p. 5).

The Sámiid Riikkasearvi report stressed the importance of Saami traditional knowledge, which is often specific to the area in question, and how environmental impact assessments often exclude dimensions such as the meaning of the landscape and cultural effects for the Saami. As a result, many of the values that are crucial for the Saami culture and living environment are not included and the Saami communities have difficulties recognising themselves in the assessments.

It is also stressed that consultants who work together with the Saami communities need to have basic knowledge of reindeer herding and the Saami culture to prevent assessment fatigue among the participating Saami, if they are expected to time and again educate developers on these issues [50] (pp. 6, 16). Similar concerns are raised by the Sámediggi in their policy documents $[46,47,52]$. There is a general call for an overall formalization of the process, with written agreements between developers and Saami communities and clearly defined steps, as well as a responsibility for the developer to provide the (economic) means for Saami participation so that the parties can meet on equal terms [50] (p. 16). A formalization of the process would safeguard the rights of the weaker party and provide the opportunity for the Saami to address important social impact factors. However, even in cases where assessments have been made together with the Saami, there is a risk that Saami traditional knowledge is dismissed with reference to its alleged lack of scientific value, unless it is also supported by academic research [42], see also [43,53].

Discussion: The arguments from Saami groups to be acknowledged as worthy partners in the work for sustainable development rests on the idea that the state needs to give them that mandate, as legitimate stakeholders in matters of interest to them. In their policy documents, the Saami organisations are arguing for the right to be consulted and to a have a greater stake in environmental management, usually in the form of co-management arrangements over important sites and resources, or at least to be consulted before developments. Co-management is presented as not only beneficial for Saami communities but 
also for their co-management partners and the entire society since the Saami traditional ways of life and traditional knowledge is claimed to have the capacity to contribute to a more sustainable development for all. The Saami organisations are therefore positioning the Saami as capable environmental stewards, with a historical track record of using but not abusing the environment and with a special conservation ethics to sustain biodiversity and to create a sustainable development.

However, in recent years, the Saami are increasingly taking a rightsholders' position, such as in the mining policy, where the Saami argue that any mining development in the reindeer herding area without the consent of local Saami groups is a violation of Indigenous peoples' human rights. Increasingly also, the Saami claims are receiving support from international rights' bodies such as CERD, that is recommending the Swedish state to take an active role in ensuring that the rights of the Saami are respected, and that they should be able to give their free, prior, and informed consent to developments.

The Swedish state representatives have been persistently reluctant to ratify any convention that would provide the Saami with full rights as an Indigenous people and refer to legal difficulties and possible conflicts between Saami and other groups in Sápmi. However, what the Swedish state representatives are reluctant to point out is that if the Saami were to have full rights, as expressed in international conventions and declarations, and be able to stop any unwanted development in the reindeer herding area, incomes from nationally important assets such as mining, forestry, and wind- and hydropower in $50 \%$ of the land area of Sweden would be in jeopardy.

Furthermore, the legal recognition of the Saami as a People sets it apart from the other four national minorities in Sweden and invites discussions about Saami self-determination, although this issue has not yet been on the agenda for negotiations between Saami representatives and the Swedish state. Instead, the Swedish state is careful to point out that although free, prior, and informed consent to developments in Sápmi is a good idea, it does not mean that the Saami are entitled to veto unwanted developments.

Until the Swedish states recognises the Saami as an Indigenous people in the international sense, and not only in the Swedish lightweight version, the Saami need to position themselves strategically to be able to influence matters of importance to them. However, if Saami people were to be acknowledged as rightsholders, and perceive themselves as such, there would not be any need for them to position themselves in any specific way, i.e., as environmentally friendly stewards for sustainable development-they would have the right regardless of what other people and Swedish authorities think of them.

\subsection{Revitalising Indigenous Tradition and the Importance of Árbediehtu/Traditional Knowledge}

At the same time as "the globalisation of law" and a global regime of indigenous rights have emerged, there has been a parallel global movement of indigenous cultural revitalisation. This has been described as a "quiet revolution" in Aboriginal Australia [54] a "cultural renaissance" among the Māori in Aotearoa New Zealand [55] (p. 10), an "ethnic renewal" and a "resurgence of identity" in the USA [56] and as a "comeback" for Aboriginal peoples in Canada [57]. Our era has been described by Clifford as a moment of global indigeneity in which Indigenous peoples have emerged "from history's blind spot" to reconnect with their cultural heritage and lost lands [58] (p. 13). This indigenous revolution has been analysed within the frameworks of a (post-)colonial revitalisation of indigenous cultures and languages and has influenced an increasing interest in indigenous traditional knowledge and natural and cultural heritage.

Some scholars have described the process as a return to and renewal of historical traditions, while others argue that it goes beyond a mere reproduction of the past and instead points at something new and creative. The concept of 'indigenous efflorescence' has been introduced to both describe "the multi-sited demographic and cultural flourishing" of Indigenous peoples and to use it as a critical analytical tool for the contemporary situation for Indigenous peoples as "something exceeding the recreation of the past" [59] (p. 7) for to be Indigenous in the 21st century is not about reproducing precolonial ways of 
being, but to translate and transform them into the present [58]. 'Tradition' is viewed as a process of cultural construction [60] (p. 398), in which 'traditional' is an ascribed and not an objective property of phenomena [61] (p. 286) and therefore not necessarily stable [62] (p. 239). Glassie has famously defined tradition as "the creation of the future out of the past" [60] (p. 395), and the explicit connection that is made between traditional knowledge and ancestral practices is meant to validate current as well as future practices.

To build a sustainable future, references to traditions are legitimised in a process of cultural revitalisation of indigenous societies. The acknowledgement of tradition and traditional culture by others is also an important part of revitalisation processes, and expressive and visual culture is relatively easy for others to accept. The Saami have used, for instance, culinary practices and handicraft as ways to take control over their own knowledge production and history [63] (p. 20) and in recent years, Saami authors, film directors, and artists within music and fine arts have also received increasing attention, nationally as well as internationally, for the combination of artistic quality and politically strong messages in books, films, songs, and art. Examples include the film "Sameblod" (Saami Blood) from 2015, by Amanda Kernell, which reached a wide audience nationally and internationally with its strong and historically accurate story of how the Saami suffered from racist ideologies and humiliating treatment. The highly acclaimed French-Swedish TV-series "Midnattssol" (Midnight Sun) features Saami actors, landscapes, and issues. Singer and musician Sofia Jannok uses her songs to advocate decolonisation messages and singers Maxida Märak and Jon Henric Fjällgren communicate their Saami experiences across multiple audiences. In 2016, the Saami youth and children's books author Ann-Helén Laestadius was awarded the "Augustpriset", one of Sweden's finest literature awards, for the book "Tio över ett" (Ten past one), which tells the story of how a Saami girl deals with the stress generated by the mining operations under her house, and the popular book "Herrarna satte oss hit" (The (gentle)men put us here) by Elin Anna Labba (2020) told the story of the forced migrations of Saami in the early 20th century. The Röhsska design museum in Stockholm also recently produced an exhibition fea-turing contemporary Saami designers (2017) with the telling title "Sápmi runt hörnet" (Sápmi around the corner).

Saami languages and visual culture have become increasingly important in the transmission of knowledge about Saami issues, and a source of pride. In September 2020, the Sámediggi submitted a draft Action programme to the Swedish government, identifying the necessary measures to "preserve, revitalise, and further develop" the Saami languages, with the aim of making them "living languages, flourishing and valued in the society" [64] (p. 16).

'Revitalisation' as derived from Wallace [65] (see Dahlin and Svensson, this issue, for an elaboration of this framework) is thus more than a general 'comeback' - it is a dynamic process with inherent ontological dimensions. Perceptions of traditional knowledge and its connection to a traditional Saami way of life, including Saami languages and culture, are perceived of as holding promises for the future, in line with Wallace's idea of revitalisation as creating a 'more satisfying culture'. The political message conveyed in contemporary Saami culture is also an important part of the Saami revitalisation process. In the Eallinbiras program (Saami Environmental Program) adopted by the Sámediggi in 2021, the Saami position themselves vis-á-vis what they refer to as a 'Western' view of culture, and argue that because of colonisation, they have had to learn Western values, including the Swedish language and Christianity, but also the languages of science, pedagogy, law, and capitalism. However, the Saami have continued to honour their "ancestors and respect their knowledge and wisdom" [66] (p. 5) and echoing global rights perspectives the Saami traditional ways of life are now presented as better alternatives to 'Western' culture.

One significant aspect in the emerging global framework of indigenous rights and cultural revitalisation is the concept of traditional knowledge. Tradition appears in identity management for the Saami and Indigenous peoples elsewhere, as it is about engaging in core cultural values. Traditionalisation has become an important strategy in the identity politics of Indigenous peoples, who need to demonstrate their maintenance of shared 
cultural traits, practices, and identities over time, despite assimilation processes. Referring to common traditions, "traditionalisation ensures the future of these practices and gives them stability" [67] (p. 90,91) and tradition is often used to produce a coherent identity of heterogeneous groups [68] (p. 1). Also, globalisation as a "way of organizing heterogeneity" has contributed to indigenous homogenisation [69] (p. 10) by its emphasis on indigenous traditions as unique, but at the same time shared by Indigenous peoples everywhere. Traditional knowledge as a global indigenous category is therefore presented as an alternative ontology with great potential in responding to the (environmental) challenges faced by humanity.

Being able to refer to indigenous rights claims at the global level has strengthened the Saami political mobilization and cultural revitalisation in Sweden. It has also identified a need to address issues of relevance specifically to the Saami in the Swedish context, and to find a middle ground on which to negotiate with Swedish authorities on more equal terms. The power of language in policy documents has become increasingly interesting to the Saami in these negotiations, and Swedish words used in conventional policy documents are being challenged and sometimes replaced if they do not accurately correspond to Saami perceptions.

It should be noted that one of the most common expressions for environmental management used in the documents in this study is the Swedish word "förvalta" which can be read more bureaucratically as to "administer" or "manage", but it can also mean to "care for" or "hold in trust" and thus has a more "spiritual" dimension as well. The Swedish concepts of "förvaltare/förvaltarskap" is translated with "steward/stewardship" in this study. Another Swedish word that has been used in the most recent policy documents is "vägvisare" which means "pathfinder", i.e., people who literally "show the way" forward, in this context leading towards a sustainable way of life and a more satisfying culture for all.

While all the analysed policy documents in this study are framed by the claim of a specific indigenous worldview (and consequently, specific rights), the policy documents generally adopt a technocratic vocabulary and procedures, and refer to concepts such as impact assessments, green infrastructure, ecosystem services, and "renbruksplaner" (plans for reindeer herding). The Sámediggi is a government body, and as such part of a bureaucratic and administrative system which sets the limits for what it can do and how it can express itself, both in form and content. The introduction of renbruksplaner is motivated by a need for developers and authorities to better understand the needs of the reindeer herding, but it also entails a formalisation and bureaucratisation of the work of reindeer herders, requiring different competences and taking time and resources from the work of actual herding. The renbruksplaner is but one example of the adjustments that the Saami need to make to be able to enter the right negotiations. However, there is little reflection in the documents regarding this form of "cultural appropriation" [53] and the need for Saami reindeer herders to comply with the Swedish bureaucracy to be heard.

The international concepts of "green infrastructure" and "ecosystem services" (focus areas in, for instance, the EU Commission's Green Infrastructure Strategy) have found their way into public administration in Sweden, and the Sámediggi presents both these concepts as in line with a Saami worldview. Green infrastructure, the Sámediggi argues, actually "asks questions that the Saami have always asked, by lifting the functionality of the ecosystems, focus on quality, contexts, and distances in the landscape and on the possibilities for species to spread and move around in the landscape." It is possible to say, it is added, "that the Saami and the reindeer have lived the green infrastructure" [70]. However, both "green infrastructure" and "ecosystem services" are arguably concepts that are deeply entrenched in the Western environmental discourse, echoing a separation between nature and culture that is incompatible with Saami worldviews. The problem with translating Western concepts to Saami equivalents is not discussed, but in the new Eallinbiras policy document (the Saami Environmental Program) these concepts are referred to as "Western" [66] (p. 8). It is only recently that the Saami have started to use Saami 
words in policy documents to better reflect their worldviews. However, some of these Saami terms, such as árbediehtu for traditional knowledge, which has been constructed to correspond to the international concept of "traditional knowledge" and is made up of the Saami words for "inheritance" or "heritage" and "knowledge" [50] (p. 38), are constructed in response to administrative processes, academic concepts, and global legal developments.

To counteract the assimilation of Saami traditional knowledge, concepts, and worldviews into Swedish policy and vocabulary, at the risk of essential meanings getting lost in translation and of being neutralised in conventional Swedish environmental management policies, initiatives have been taken by the Swedish government to support Saami-led projects about traditional knowledge.

The adoption of the CBD in 1992 highlighted Indigenous peoples and local communities and their traditional knowledge, and the articles 8(j) and 10(c) have had a profound impact on Indigenous peoples' policy work. Inspired by the global development of indigenous rights, Saami scholars identified the negative effects of Western lifestyles for the Saami, arguing that the Saami culture is based on adapting to natural conditions and that according to Saami ecological ethics they should "use nature, and not abuse it" [71] (p. 53). It was also argued that the way Indigenous peoples, including the Saami, use and value nature should be seen as a guarantee for good conservation and sustainable use of biodiversity [72] (p. 22, 23). In a report about traditional knowledge from 2007, it was claimed that "a stronger protection for Saami traditional land use can be important for biodiversity" [72] (p. 12) and that

"traditional Saami knowledge can also have an added value if it is applied in for instance natural resource management and is therefore not only important for the Saami society but also for the Swedish society at large, and also in an international perspective" [73] (p. 110).

Furthermore, it was argued that

"since Indigenous peoples have existed long enough in their traditional areas, they "can be assumed to be able to preserve and sustainably use the biodiversity". Therefore, indigenous societies are supposed to be able to contribute to alternative evaluations and usage of the ecosystems that are "relevant for the preservation and sustainable use of biodiversity" [73] (p. 29).

In the wake of the adoption of a working programme regarding traditional knowledge within the CBD, in 2000, the Swedish government assigned the Swedish Biodiversity Centre in 2006 to develop a Swedish national programme for local and traditional knowledge related to conservation and sustainable use of biological diversity (NAPTEK). Issues related to Saami traditional knowledge were to be based on consultation and cooperation with the Sámediggi, which started a capacity building process concerning traditional knowledge for the Sámediggi. The first Saami related activity in that collaboration was a survey over the indigenous involvement in previous documentation and research related to Saami traditional knowledge, which resulted in an overview report [73]. According to the report, most of the previous activities had not been performed by Saami or planned from a Saami perspective. The report was discussed by the Saami politicians in the Sámediggi plenary meeting in May 2007 and resulted in a second step, when local Saami organisations could apply for grants to perform a total of 14 pilot documentation projects in 2007-2009 in order to be able to reflect upon the difference in focus, when documentation projects were managed by Saami organisations instead of non-Saami scholars and state authorities [74] (pp. 52-55).

The third step in the cooperation was a proposition from the Sámediggi to develop, in a collaborative way, a policy for Saami traditional knowledge as well as ethical guidelines for Saami-related research. In 2010, the Swedish Sámediggi adopted a policy for árbediehtu, which explicitly connects the Saami traditional knowledge to an indigenous paradigm made up of a diversity of local traditions that share some common characteristics [75] (p. 13). The term árbediehtu has been constructed to correspond to the international concept of 
"traditional knowledge" and is made up of the Saami words for "inheritance" or "heritage" and "knowledge" [50] (p. 38). The term árbediehtu emphasises the relation of the knowledge to the past and its continuity to the present as well as the way the knowledge is transmitted between generations $[73,75]$. The document refers to the CBD, articles $8(\mathrm{j})$ and $10(\mathrm{c})$, as an international legal framework that protects traditional indigenous knowledge, but the document suggests that the Saami seem to understand traditional knowledge in broader terms than those provided in 8(j) [75] (p. 15) and the document therefore expresses a Saami right of interpretation to what is meant by árbediehtu [75] (p. 16). The creation of this term, and various attempts to document and define this type of knowledge can be seen as further examples of local contexts being aligned to a global framework. The integration of árbediehtu "on all levels" is seen to create a society permeated by Saami norms, values, and ways of thinking. Árbediehtu is also presented as something that will benefit the Swedish society at large, for example in relation to long-term ecological sustainability and biodiversity [75] (p. 4).

The concept of árbediehtu is based on a worldview that does not separate nature and culture along the lines of Western thought. It is presented as place-based knowledge and frequently referred to in documents dealing with land and resource use: past, present, and future. According to the Sámiid Riikkasearvi in a report on Saami land use, árbediehtu

"entails valuable knowledge about the local environment that has been observed for a very long time and which can provide a historical perspective of the biological, social, and cultural changes that have affected the environment" [50] (p. 39).

Traditional Saami views are said to be based on a view of nature that also differs from a Western worldview in that it originates from a spiritual appreciation of nature and views the relationship between humans and their environment in moral and ethical terms [75] (p. 5), as these are

"values that are connected to nature and which originates from the spiritual values that nature has for the Saami. This knowledge includes, for instance, the moral and ethical issues of the relationship between humans, animals, and the environment, about what is "the right way" of doing things" [50] (p. 39).

Árbediehtu is however not to be seen as dated knowledge of no relevance to the current situation, as it is not "a static wisdom but is developed and changed in tune with the changes in the circumstances" [50] (p. 39), cf. [75] (p. 8). According to the Sámediggi, árbediehtu is useful for the sustainable management of lands and resources and should be included in environmental assessment processes. Árbediehtu is not, however, only about managing material resources to create a good life but provides guidance also on an immaterial level [66] (p. 6).

The transmission of árbediehtu, as well as the knowledge itself, is linked to a specific Saami way of life. Oral and participatory transmission of knowledge between generations is considered natural, and children learn by taking part in activities. Changing ways of living for many Saami and fewer speakers of Saami languages have however provided obstacles for this natural transmission and have also challenged the relevance of traditional knowledge associated with previous activities and needs [66] (p. 8).

Traditional knowledge is also presented as a key to accessing knowledge about the Saami heritage as heritage sites and archaeological remains are integrated into the landscape, but often invisible to the untrained eye. Being able to read and interpret the landscape and its Saami cultural remains is presented as a unique Saami ability that others do not possess [66] (p. 11). Árbediehtu can also include knowledge of the weather, and skills such as knowing how and where to fish, hunt, or pick berries and how produce from these ventures is prepared, how reindeer move in the landscape and what vegetation they graze and how buildings and tools can be created from nature's materials. Furthermore, árbediehtu "is to take care of nature's life cycle, to save everything with care, reuse, repair, 
and nurture. To not take more than one needs. To not destroy and be grateful for what nature gives." [66] (p. 6)

Árbediehtu, according to the Saami, can not only contribute to the sustainable development of their own traditional areas, but to sustainability more generally. It is argued by the Saami that

"our story is about how the Saami traditionally view the world, what makes us call ourselves pathfinders for the new times and pathfinders for a sustainable society (...) Árbediehtu and the Saami landscape perspective enrich the debate in society both for us Saami and for society in general in many issues, for instance long-term ecologically sustainability and biodiversity" [76].

The loss of árbediehtu is thus seen as a loss not only for the Saami, but for Swedish society in general. According to the Eallinbiras program, the participation by Saami in management "where consideration is taken to árbediehtu" can benefit both biodiversity and provide opportunities to long-term economic development more generally and especially in rural areas [66] (p. 12).

In the Sámediggi's environmental program [66], it is argued that there is an interrelationship between Saami languages, árbediehtu and biodiversity and that a loss of biodiversity and the destruction of ecosystems would result in a subsequent loss of related language and knowledge. It is pointed out that

"the richness of Saami words when it comes to for example describing the features of nature and different kinds of snow illustrate how interconnected language, culture, and nature are" [66] (p. 8).

Whereas the Saami languages are important for accessing Saami traditional knowledge of the lands and resources, the Saami land use has been "a natural part of the ecosystem in the forest- and mountain landscape and a precondition for the preservation of the character of the area as a used landscape and with a plurality of flora". Reindeer herding is "an important indicator for the natural environment, biodiversity and for the condition of the coherent landscape and the ecosystems in which is exists" and is therefore "an important contribution to Swedish environmental and nature conservation work". The protection of a viable reindeer herding is also crucial "for Sweden to reach its national and international targets related to biodiversity" [66] (p. 8).

It is also argued in the Sámediggi's policy document for traditional knowledge that in international contexts, "traditional knowledge of Indigenous peoples has been identified as valuable and necessary for the conservation and usage of biodiversity" and that conversely "biodiversity is the foundation for the preservation of indigenous and local societies' traditional knowledge and customs". This intimate relationship between biodiversity, traditional knowledge, and indigenous and local societies' management of lands and biological resources is also expressed in the CBD, articles 8(j) and 10(c) [66] (p. 8). The relationship is also confirmed in a missive from the Sámediggi to the Swedish government regarding Saami traditional knowledge, where it is argued that "the conservation of biodiversity goes hand in hand with the preservation of cultural diversity, and the customary use by indigenous and local societies promotes biodiversity" [77] (p. 22).

These statements are also echoed in the work with developing the Swedish environmental quality goals. The Swedish government has stated that the preservation and use of local and traditional knowledge relating to the preservation and sustainable use of biodiversity is important for the possibilities to reach the goals for biological resources. [66] (p. 9) and in the Sámediggi's Climate Strategy [52], it is not only argued that the Saami traditional knowledge can be useful for biodiversity, but that

"the Saami are pathfinders for a sustainable society where the carrying capacity of nature with high biodiversity and an intact, coherent landscape are important preconditions."

Statements like these reflect the development of Saami arguments and how they partly expand previous claims for positions as stakeholders or rightsholders, by arguing that 
Swedish authorities can learn about sustainability not only by acknowledging the value of árbediehtu for the Saami, but by following their lead.

Discussion: The globalisation of law and the development of Indigenous peoples' rights have fuelled their cultural revitalisation processes and highlighted tradition as a useful source for indigenous mobilisation. In a process of traditionalisation, the Saami have increasingly used their culture to engage in expressive and visual arts and to revitalise the use of the Saami languages. The cultural expressions are often based on grievances over encroachments and discrimination by the Swedish state and convey strong messages about the need for redress for past wrongs. The Saami have also, inspired by international processes, increasingly focused on árbediehtu as important not only for cultural revitalisation and Saami identity, but for accessing valuable skills and knowledge to maintain sustainable lifestyles and the preservation of biodiversity.

For many years, the Saami organisations have had to comply with conventional Swedish environmental management policies and terminology to be recognised as stakeholders, and Saami policies still reflect the mainstream technocratic vocabulary that is characteristic for Swedish bureaucracy. However, in recent years, compliance has begun to change to resistance, as reflected, for instance, in the differentiation that is made between Swedish and Saami worldviews and in the increasing use of Saami concepts, such as árbediehtu. These concepts to some degree embody perspectives that corresponds to global indigenous concepts and legal discourse, but are also used to reflect a distinctly Saami experience.

In the policy documents, the Saami organisations are presenting their worldview as different from Western worldviews, which according to the Saami are characterised by a division between the environment and (its) people, and by unsustainable ways of using the environment. By contrast, the Saami worldview is presented as holistic and based on a conservation ethic that permits the use, but not the abuse, of the environment. However, it is only with difficulty and a high risk for misunderstandings that the Saami holistic worldview can be perceived or described using Western, in this case Swedish, concepts. The introduction of the concept of árbediehtu can therefore be seen as an attempt from Saami organisations to both introduce a concept that makes sense to the Saami, and to take control over their traditional knowledge and protect it from appropriation by Swedish authorities. The resistance from Saami organisations against adaptation and assimilation as ways to gain acceptance for árbediehtu and Saami ways of life is also reflected in the presentation of themselves as pathfinders for sustainability. By arguing that árbediehtu entails valuable knowledge and skills for creating sustainable development, the Saami organisations are taking their own initiative and present themselves as leaders-not followers. The emphasis that is placed in Saami policy documents on their holistic worldview is also contrasted with the tendency of Swedish authorities to treat environmental and cultural issues as separate questions, to be managed by different authorities and at different levels of administration. This is also, according to the Saami organisations, one of the reasons for why conventional Western environmental management approaches are unsustainable. The Saami holistic worldview is also reflected in the way Saami organisations present their arguments for better rights. When Saami organisations criticize the lack of consultations before extractions, they often do so with reference not only to possible environmental damage or for disturbing the reindeer, but to risks for damaging their culture, language and by extension their identity as Saami. This integration of issues is also reflected in the use of árbediehtu, that is simply described as valuable knowledge about the right ways of doing things, that can be used to create sustainable development and (as a result) a more satisfying culture, not only for the Saami but for the Swedish society generally.

\section{Conclusions}

The Saami struggles for rights have intensified during the last decades parallel to the development of a "globalisation of law" and an increasing exchange of ideas and experiences on the international level. The global development of Indigenous peoples' rights 
issues and the Saami struggles have become mutually reinforcing processes which have resulted in a revitalisation of the Saami culture and society in Sweden and an increasing Saami focus on sustainability.

The rhetoric used by the Saami in their political struggles for rights is not only based on their status as an Indigenous people, but also on arguments about the inherent sustainability of the traditional Saami way of life. The Saami also argue that they have traditional ecological ethics that make them particularly suitable as stewards of their traditional lands. Granting the Saami rights and control over land and resources, then, entails a promise of a more environmentally friendly and sustainable development, at least in Sápmi, but policy positions have emerged suggesting that the acknowledgment and implementation of Saami sustainable development principles would also benefit Sweden generally.

The idea that the Saami as an Indigenous people is in possession of a sustainable lifestyle based on traditional knowledge is strongly supported by global discourses about indigenous rights and strategies for sustainable development. As part of their cultural revitalisation, the Saami are also increasingly using their own interpretation of global policies and are creating and presenting Saami concepts and their own priorities to better reflect their worldviews.

Although the Saami arguments for greater influence over their traditional areas and resources are guided by international progress in law on indigenous rights and supported by international conventions and policies, Saami rights in Sweden today are not based on their status as an Indigenous people or a People, but as an ethnic and linguistic minority, and in local contexts the Saami are still mostly seen as "stakeholders" with possible users' rights instead of "rightsholders".

Successive Swedish governments, and up until recently also the courts, have dismissed Saami claims based on Indigeneity and instead referred to the Saami immemorial rights to customary practices, or to their cultural rights as a minority. The reluctance of the state to acknowledge Saami indigenous rights has obstructed the Saami struggles for better control over lands and resources and has forced the Saami to navigate the national political landscape by positioning themselves as "environmentally friendly" and consequently natural allies for the state in the efforts to create sustainable development.

The increasing focus on árbediehtu, their traditional knowledge, reflects its importance as a comprehensive concept designating not only specific knowledge and skills associated with traditional Saami livelihoods, but spiritual dimensions of Saami culture, Saami languages, worldview, and environmental ethics, as well as a source of valuable knowledge of sustainable lifestyles.

In the policy documents, the Saami organisations are presenting their worldview as distinct and different from Western worldviews, which according to the Saami are characterised by a division between nature and culture and by unsustainable ways of using the environment. By contrast, the Saami worldview is presented as holistic and based on sustainable ways of life. Supported by international conventions and policies, the Saami have been able to argue that their traditional knowledge and sustainable way of life should not only be recognized by Swedish authorities but could also serve as a source of inspiration. In Saami policy documents, they have presented themselves as pathfinders for a sustainable future, and their sustainable way of life as a model for others to follow. Expressed differently, a recognition of Saami árbediehtu and sustainable ways of life is considered to hold a promise of a better future for all.

Author Contributions: Conceptualization, Å.N.D. and J.D.; document compilation, all authors; methodology, Å.N.D. and J.D.; formal analysis, all authors; writing—original draft preparation, all authors; writing - review and editing, all authors; project administration, J.D. All authors have read and agreed to the published version of the manuscript.

Funding: This research received no external funding.

Informed Consent Statement: We have only used publicly available material. 
Data Availability Statement: No new data were created or analysed in this study. Data sharing is not applicable to this article.

Conflicts of Interest: The authors declare no conflict of interest.

\section{References}

1. Sámediggi. Analysis of Sápmi. Regional SWOT Analysis Prepared for the 2014-2020 Rural Development Programme and Maritime E Fisheries Fund; Sámediggi: Kiruna, Sweden, 2014.

2. Sámediggi. Samerna i Sverige. Available online: https://www.sametinget.se/samer (accessed on 1 September 2021).

3. Mörkenstam, U. Organised hypocrisy? The implementation of the international indigenous rights regime in Sweden. Int. J. Hum. Rights 2019, 23, 1718-1741. [CrossRef]

4. Lawler, P. The 'Good State' Debate in International Relations. Int. Politics 2013, 50, 18-37. [CrossRef]

5. Bergman, A. The co-constitution of domestic and international welfare obligations: The case of Sweden's social democratically inspired internationalism. Coop. Confl. 2007, 42, 73-99. [CrossRef]

6. Bergman Rosamond, A. Swedish Internationalism and Development Aid. In The Oxford Handbook of Swedish Politics; Pierre, J., Ed.; Oxford University Press: Oxford, UK, 2015; pp. 462-478.

7. Kløcker Larsen, R.; Raitio, K. Implementing the state duty to consult in land and resource decisions: Perspectives from Sami communities and Swedish state officials. Arct. Rev. Law Politics 2019, 10, 4-23. [CrossRef]

8. Lawrence, R.; Mortiz, S. Mining industry perspectives on indigenous rights: Corporate complacency and political uncertainty. Extr. Ind. Soc. 2018, 6, 41-49. [CrossRef]

9. Salminen, S. (Un)narrating Belonging-Colonial Imaginaries and Gender Equal Nordic Subjects—Sámi Contestations; Lund University: Lund, Sweden, 2018.

10. Mulinari, D.; Keskinen, S.; Irni, S.; Tuori, S. Introduction: Postcolonialism and the Nordic Models of Welfare and Gender. Complying with Colonialism. In Gender, Race and Ethnicity in the Nordic Region; Keskinen, S.T., Irni, S., Mulinari, D., Eds.; Ashgate: Farnham, UK, 2009; pp. 15-46.

11. Nyström, M. Narratives of Truth: An Exploration of Narrative Theory as a Tool in Decolonising Research. In Indigenous Effloresence. Beyond Revitalisation in Sápmi and Ainu Mosir; Roche, G., Kroik, Å.V., Maruyama, H., Eds.; Australian National University Press: Canberra, Australia, 2018.

12. Grey, S.; Kuokkanen, R. Indigenous governance of cultural heritage: Searching for alternatives to comanagement. Int. J. Herit. Stud. 2019, 26, 919-941. [CrossRef]

13. Tervaniemi, S.; Magga, P. Belonging to Sápmi-Sámi Conceptions of Home and Home Region; Thomas Hylland Eriksen, S.V., Valkonen, J., Eds.; Routledge: London, UK, 2018.

14. Össbo, Å.; Lantto, P. Colonial Tutelage and Industrial Colonialism: Reindeer husbandry and early 20th-century hydroelectric development in Sweden. Scand. J. Hist. 2011, 36, 324-348. [CrossRef]

15. Fur, G. Colonialism and Swedish History: Unthinkable Connections? In Scandinavian Colonialism and the Rise of Modernity. Contributions To Global Historical Archaeology; Naum, M.N.J., Ed.; Springer: New York, NY, USA, 2013 ; Volume 37.

16. Mörkenstam, U. The Constitution of the Swedish Sámi People: Swedish Sámi Policy and the Justification of the Inner Colonisation of Sweden. In Becoming Minority: How Discourses and Policies Produce Minorities in Europe and India; Tripathy, J., Padmanabhan, S., Eds.; SAGE: London, UK, 2014.

17. Sörlin, S. Framtidslandet: Debatten Om Norrland Och Naturresurserna Under Det Industriella Genombrottet; Carlsson Bokförlag: Stockholm, Sweden, 1988.

18. Lundmark, L. Stulet Land: Svensk Makt På Samisk Mark [Stolen Land: Swedish Power in Saami Land]; Ordfront: Stockholm, Sweden, 2008.

19. Persson, M.; Öhman, M. Visions for a Future at the Source: The Battle against the Rönnbäck Nickel Mining Project; Uppsala Universitet: Uppsala, Sweden, 2014.

20. Hedström, J.-O. Igenom Gode Ordningar och Flitigt Uppseende: Bergsstaten 375 år [Through Good Order and diligent attention: Bergsstaten 375 Years]; Bergsstaten, Sveriges Geologiska Undersökning (SGU): Uppsala, Sweden, 2012.

21. Lawrence, R.; Åhrén, M. Mining as Colonization: The Need for Restorative Justice and Restitution of Traditional Sámi Lands. In Nature, Temporality, and Environmental Management. Scandinavian and Australian Perspectives on Peoples and Landscapes; Routledge: London, UK, 2017.

22. Cramér, T.; Ryd, L. Tusen år i Lappmarken; Ord och Visor Förlag: Skellefteå, Sweden, 2012.

23. Bylund, E. Koloniseringen av Pite Lappmark t.o.m. 1867; Almqvist \& Wiksell: Uppsala, Sweden, 1956.

24. Arell, N. Kolonisationen i lappmarken. Några Näringspolitiska Aspekter; Esselte Studium: Stockholm/Göteborg/Lund, Sweden, 1977.

25. Allard, C.; Brännström, M. Girjas sameby mot staten: En analys av Girjasdomen. Sven. Juristtidning 2020, 429-452.

26. Beach, H.; Anderson, M.; Aikio, P. Dynamics of Saami Territoriality within the Nation-States of Norway, Sweden and Finland. Mobility and Territoriality; Routledge: London, UK, 1992.

27. Riikkasearvi, S. Samiskt vägval. Agenda 21-Handlingsplan i Miljö och Demokratifrågor; Sámiid Riikkasearvi: Umeå, Sweden, 1996.

28. IPBES. Summary for Policymakers of the Global Assessment Report on Biodiversity and Ecosystem Services of the Intergovernmental Science-Policy Platform on Biodiversity and Ecosystem Services; IPBES Secretariat: Bonn, Germany, 2019. 
29. Colfer, C.J.P. Implications of adaptive collaborative management for more equitable forest management. In The Equitable Forest: Diversity, Community and Resource Management; Colfer, C.J.P., Ed.; CIFOR: Bogor, Indonesia, 2005; pp. 256-273.

30. Lu, D.-J.; Chueh, H.-C.; Kao, C.-W. Why They Cannot Work Together: A Study of the Co-Management of Natural Resources with Indigenous People in Taiwan. Soc. Nat. Resour. 2012, 25, 105-111. [CrossRef]

31. Holling, C.S.; Meffe, G.K. Command and Control and the Pathology of Natural Resource Management. Conserv. Biol. 1996, 10, 328-337. [CrossRef]

32. Berkes, F. Property rights and coastal fisheries. In Proceedings of the Community Management and Common Property of Coastal Fisheries in Asia and the Pacific: Concepts, Methods and Experiences, Manila, Philippines, 21-23 June 1994; pp. 51-62.

33. Yandle, T. The challenge of building successful stakeholder organizations: New Zealand's experience in developing a fisheries co-management regime. Mar. Policy 2003, 27, 179-192. [CrossRef]

34. Carlsson, L.; Berkes, F. Co-management: Concepts and methodological implications. J. Environ. Manag. 2005, 75, 65-76. [CrossRef]

35. Plummer, R.; Fitzgibbon, J. Co-management of Natural Resources: A Proposed Framework. Environ. Manag. 2004, 33, 876-885. [CrossRef] [PubMed]

36. Imai, S. Indigenous Self-Determination and the State. In Indigenous Peoples and the Law: Comparative and Critical Perspectives; Richardson, B.J., Imai, S., McNeil, K., Eds.; Hart: Oxford, UK; Portland, OR, USA, 2009; pp. 285-314.

37. Mulrennan, M.E.; Scott, C.H. Co-management-An Attainable Partnership? Two Cases from James Bay, Northern Quebec and Torres Strait, Northern Queensland. Anthropol. Forum 2005, 47, 197-213.

38. Arnstein, S.R. A Ladder of Citizen Participation. J. Am. Plann. Assoc. 1969, 35, 216-224. [CrossRef]

39. Maraud, S.; Guyot, S. Mobilization of Imaginaries to Build Nordic Indigenous Natures. Polar Geogr. 2016, 39, 196-216. [CrossRef]

40. Scheinin, M. The right of a people to enjoy its culture: Towards a Nordic Saami rights convention. In Cultural Human Rights; Francioni, F., Scheinin, M., Eds.; Martinus Nijhoff Publishers: Leiden, The Netherlands, 2008.

41. Kløcker Larsen, R.; Raitio, K.; Stinnerborn, M.; Wik-Karlsson, J. Sámi-State Collaboration in the Governance of Cumulative Effects Assessment: A Critical Action Research Approach. Environ. Impact Assess. Rev. 2017, 64, 67-76. [CrossRef]

42. Sámediggi. Uttalande om Girjasdomen [Comments on the Girjas Trial]. Available online: https://www.sametinget.se/149884 (accessed on 1 September 2021).

43. Nilsson Dahlström, Å. Negotiating Wilderness in a Cultural Landscape: Predators and Saami Reindeer Herding in the Laponian World Heritage Area; Acta Universitatis Upsaliensis: Uppsala, Sweden, 2003.

44. Mijá Ednam: Samebyarnas Laponiaprogram (The Laponia Program from the Reindeer Herding Communities); Samebyarnas Kansli (Office of the Reindeer Herding Communities): Jokkmokk, Sweden, 1999.

45. Laponiaförordning/Laponia Regulation, SFS 2011:840. 2011. Available online: https://www.riksdagen.se/sv/dokument-lagar/ dokument/svensk-forfattningssamling/laponiaforordning-2011840_sfs-2011-840 (accessed on 16 August 2021).

46. Sámediggi. Sametingets syn på Vindkraft i Sápmi; Sámediggi: Kiruna, Sweden, 2009.

47. Sámediggi. Sametingets syn på Gruvor och Mineraler i Sápmi; Sámediggi: Kiruna, Sweden, 2014.

48. Dahlin, J. Hur stor är en gruva? Överlappande problemområden i en handläggningsprocess. Nord. Adm. Tidsskr. 2021, 98, 1-24. [CrossRef]

49. Acosta, A. Extractivism and neo extractivism: Two sides of the same curse. In Beyond Development: Alternative Visions from Latin America; Lang, M., Molerani, D., Eds.; Transnational Institute: Amsterdam, The Netherlands, 2013; pp. 61-86.

50. Sámiid Riikasearvi. Samisk Markanvändning och MKB (Saami land use and Environmental Impact Assessments); Sámiid Riikasearvi (Svenska Samernas Riksförbund, SSR) \& Sametinget (Sámediggi/Saami Parliament): Umeå/Kiruna, Sweden, 2010.

51. Permanent Mission of Sweden to the United Nations. Explanation of vote at the adoption of the United Nations Declaration on the Rights of Indigenous Peoples (Res. A/61/L.67). Facsimile message. 14 September 2007.

52. Sámediggi. Klimatstrategi_Sametingets Politiska Ställningstagande; Sámediggi: Kiruna, Sweden, 2019.

53. Nilsson Dahlström, A. The Two-Way Appropriation of Indigenous Knowledge. Environmental Policies and the Laponia Process. J. North. Stud. 2009, 39-57.

54. Langton, M. Boyer Lectures 2012: The Quiet Revolution: Indigenous People and the Resources Boom; HarperCollins Australia: Sydney, Australia, 2013.

55. Walker, R. Ka Whawhai Tonu Matou: Struggle without End; Penguin: Auckland, Aotearoa, New Zealand, 2004.

56. Nagel, J. American Indian ethnic renewal: Politics and the resurgence of identity. Am. Sociol. Rev. 1995, 60, 947-965. [CrossRef]

57. Saul, J.R. The Comeback: How Aboriginals Are Reclaiming Power and Influence; Penguin: Toronto, ON, Canada, 2014.

58. Clifford, J. Returns: Becoming Indigenous in the Twenty-First Century; Harvard University Press: Cambridge, MA, USA, 2013.

59. Roche, G.; Hiroshi, M.; Kroik, Å.V. (Eds.) Indigenous Effloresence. Beyond Revitalisation in Sápmi and Ainu Mosir; Australian National University Press: Canberra, Australia, 2018.

60. Glassie, H. Tradition. J. Am. Folk. 1995, 108, 395-412. [CrossRef]

61. Handler, R.; Linnekin, J. Tradition, Genuine or Spurious. J. Am. Folk. 1984, 97, 273-290. [CrossRef]

62. Noyes, D. Tradition: Three Traditions. J. Folk. Res. 2009, 46, 233-268. [CrossRef]

63. White, R.A. Is "Empowerment" the Answer?: Current Theory and Research on Development Communication. Int. Commun. Gaz. 2004, 66, 7-24. [CrossRef]

64. Gielejarnge, S. Lägesrapport: De samiska språken i Sverige 2020 [Situation Report: The Saami Languages in Sweden 2020]; Sámediggi: Kiruna, Sweden, 2021. 
65. Wallace, A.F.C. Revitalization Movements. Am. Anthropol. 1956, 58, 264-281. [CrossRef]

66. Sámediggi. Eallinbiras/Iellembirás/Jielemen Birje; Sámediggi: Kiruna, Sweden, 2021.

67. Cocq, C. Traditionalisation for Revitalisation: Tradition as a Concept and Practice in Contemporary Sámi Contexts. Folk. Electron. J. Folk. 2014, 57, 79-100. [CrossRef]

68. Bronner, S.J. Following Tradition: Folklore in the Discourse of American Culture; Utah State University Press: Logan, UT, USA, 1998.

69. Eriksen, T.H. Globalization: The Key Concepts; Bloomsbury: London, UK, 2007.

70. Sámediggi. Grön Infrastruktur ur Rennäringsperspektiv. Available online: https://www.sametinget.se/gron-infrastruktur (accessed on 8 September 2021).

71. Helander, E. Samiska traditioner, traditionell kunskap och bärkraftig utveckling. NordNytt 1992, 46, 49-58.

72. Utsi, P.M. Traditionell kunskap och svensk samepolitiska utgångpunkter. In Árbevirolas sámi Diehtu-Traditionell Samisk Kunskap; Vetenskapliga Rådet för Biologisk Mångfald: Stockholm/Sámediggi/Kiruna, Sweden, 1997; pp. 22-25.

73. Utsi, P.M. Traditionell Kunskap och Sedvänjor inom den Samiska Kulturen—Relaterat till Bevarande och Hållbart Nyttjande av Biologisk Mångfald; Sametinget \& centrum för biologisk mångfald: Kiruna/Uppsalay, Sweden, 2007.

74. Tunón, H. Svenskt regeringsinitiativ för traditionell kunskap. In Långa Perspektiv: Samisk Forskning E Traditionell Kunskap; Sköld, P., Stoor, K., Eds.; Vaartoe-Centrum för Samisk Forskning, Umeå Universitet: Umeå, Sweden, 2012; pp. 32-58.

75. Sámediggi. Árbediehtu/Árbbediehto/Aerpimaahtoe: Sametingets Policydokument för Traditionell Kunskap; Sámediggi: Kiruna, Sweden, 2010.

76. Sámediggi. Vår berättelse [Our Story]. Available online: https://www.sametinget.se/var-berattelse (accessed on 1 September 2021).

77. Sámediggi. Traditionell kunskap för Bevarande och Hållbart Nyttjande av Biologisk Mångfald: Förslag på Åtgärder för Implementering av Artiklarna 8(j) och 10(c) i Konventionen om Biologisk Mångfald (CBD); Naturvårdverket \& Sametinget: Stockholm/Kiruna, Sweden, 2018. 